\title{
Extending the Holding Time for Agricultural Water Testing EPA Method 1603 for Produce Growers
}

\author{
Manreet Singh Bhullar ${ }^{1}$, Angela Shaw ${ }^{1, *}$, Joseph Hannan ${ }^{2}$ and Smaranda Andrews ${ }^{1}$ \\ 1 Department of Food Science and Human Nutrition, Iowa State University, Ames Iowa, IA 50011, USA; \\ manreet.bhullar@gmail.com (M.S.B.); smaranda@iastate.edu (S.A.) \\ 2 Iowa State University Extension and Outreach, Adel Iowa, IA 50003, USA; jmhannan@iastate.edu \\ * Correspondence: angelaml@iastate.edu; Tel.: +1-515-294-0868
}

Received: 14 August 2019; Accepted: 26 September 2019; Published: 28 September 2019

\begin{abstract}
Agricultural water is a known vector for the transfer of foodborne pathogens onto fresh produce. Development of pre-harvest and post-harvest microbial profiles of agricultural water used by fresh produce growers, processors, and holdings is a requirement under the Food Safety Modernization Act Produce Safety Rule. One of the United States Environmental Protection Agency (US EPA) approved agricultural water testing methods is US EPA Method 1603, which requires no greater than a 6-h time frame between the collection of the water sample and initiation of analysis. This 6-h timeframe is unrealistic for many produce growers due to there being few laboratories certified to conduct testing and the geographic location of the farms. Agricultural water samples $(\mathrm{n}=101)$ from well water and surface water were collected from 60 different farms to determine if holding samples for $24 \mathrm{~h}$ yielded significantly more generic Escherichia coli (E.coli) than $6 \mathrm{~h}$ using EPA 1603 method. A total of 32 samples were found contaminated with generic E. coli. Of these positive samples, surface water accounted for $87.5 \%$ of the samples $(n=28)$. There was no significant disparity between populations of generic E. coli at 6- and 24-h sample-test time interval $(p>0.05)$. These results provide evidence that the sample-test time interval can be extended to 24 -h time, which makes quantitative generic E. coli testing for agricultural water as mandated by the FSMA Produce Safety Rule more accessible to growers.
\end{abstract}

Keywords: agricultural water; EPA 1603; water testing; fruit; vegetable; Produce Safety Rule

\section{Introduction}

Fresh produce, which is commonly eaten raw, utilizes water in pre- and post-harvest activities including irrigation, pest management, washing, cooling, sanitation, and personal handwashing. Agriculture production is the major consumer of surface and groundwater in the United States, with $70 \%$ of agricultural water used for irrigation [1]. The microbial quality of water used in fresh produce production is a critical food safety concern, especially considering that irrigation water has been reported as a source of contamination in fresh produce [2,3].

Agricultural water microbial quality has been linked to many foodborne outbreaks in produce $[4,5]$. For instance, in January 2018, a romaine lettuce outbreak in Yuma, Arizona, was linked to irrigation water sourced from a stream that was contaminated with Escherichia coli O157:H7 (E.coli O157:H7) from a nearby cattle feedlot. This outbreak affected 172 persons in 32 states, with $45 \%$ of people hospitalized, and resulted in one death [6].

Development of an agricultural water profile can help farmers mitigate their food safety risk. There are nine approved agricultural water testing methods available under the Food Safety Modernization Act (FSMA) Produce Safety Rule [7]. United States Environment Protection Agency (US EPA) method 1603 "detection of E. coli in water by membrane filtration using modified membrane 
Thermotolerant E. coli (mTEC) media" is one of the nine approved methods. This method has a maximum 6-h time interval between collection of the sample and start of the analysis. These FSMA water requirements also apply to all the imported covered produce from other countries into the United States. With respect to water regulations globally, there are no requirements in place to regulate microbial water quality other than third party audit requests such as Safe Quality Food (SQF). Short water-holding time is a challenge in many states in the US since there are few certified laboratories equipped to do this test, and many produce farms are not located close enough to a lab to deliver the sample within the time constraint or without spending an entire day away from the farm [8]. In literature, there are studies that analyzed the extension of sample holding time, but limited information was found related to agricultural water and EPA method 1603, the only Food and Drug Administration (FDA) -approved water testing method [9-11]. To modify the requirements for water testing methods under the FSMA Produce Safety Rule, the researcher must submit comments and data through the FDA Dockets Management platform. These comments can be made with draft rule and final rule. Data must include the complete methods, results, and conclusions from the study. The objectives of this study were to determine the prevalence of generic E. coli in agricultural water used in Iowa fresh produce farms and determine if the current sample holding time for US EPA 1603 method can be extended from $6 \mathrm{~h}$ to $24 \mathrm{~h}$.

\section{Materials and Methods}

Two-hundred $\mathrm{mL}$ water samples $(\mathrm{n}=101)$ were collected from 60 fresh produce farms located throughout Iowa. A listserv of produce growers in Iowa was utilized to solicit participation in this study. Farms were chosen based on distribution throughout the state and water sources, and the ability to collect water samples within the 6-h sample holding time requirement of US EPA Method 1603 (See Figure 1). The water sampling was conducted during the growing season in Iowa (May-August) in 2017 and 2018. A subset of the total samples $(n=11)$ were sampled multiple times during the study, to accommodate growers' requests and assist with developing records and microbial water quality profile. Samples were collected from two different types of water sources: Well water (deep wells $(\mathrm{n}=63$, $>250 \mathrm{ft}$ ) and shallow wells $(\mathrm{n}=6,<60 \mathrm{ft})$, all capped), 67\%) and surface water ( $\mathrm{n}=32$, (ponds, lakes, rain harvested water), $31 \%$ ). Municipal water samples were not collected for this study as the water is treated and tested by the city daily. Samples were collected in sterile water cups (Samco Scientific, Mexico) and prepared for analysis at two-time frames: $6 \mathrm{~h}$ and $24 \mathrm{~h}$.

The temperature of the water $\left({ }^{\circ} \mathrm{C}\right)$ from the source was recorded at the time of sampling, and the water samples were stored in the range of $4-10^{\circ} \mathrm{C}$ until the time of analysis per US EPA Method 1603 [8]. However, for 24-h analysis, the samples were held at $<10^{\circ} \mathrm{C}$ for the first $6 \mathrm{~h}$ and then stored at $4{ }^{\circ} \mathrm{C}$ for the remaining $18 \mathrm{~h}$. Samples were delivered to Iowa State University BSL2 Food Microbiology Laboratory and analyzed according to the US EPA Method 1603 standard [8]. As part of this study and not included in this manuscript, the water sample results were provided to the growers to include as part of their farm water profile.

All cell count numbers were documented in colony forming unit (CFU)/100 mL values and transformed to a logarithmic scale to meet the requirements for statistical analysis. The mean differences between bacterial counts at $6 \mathrm{~h}$ and $24 \mathrm{~h}$ were calculated using paired t-test in SAS statistical computing environment (SAS 9.4, Cary, NC, USA). Statistical significance was established at $p<0.05$. 


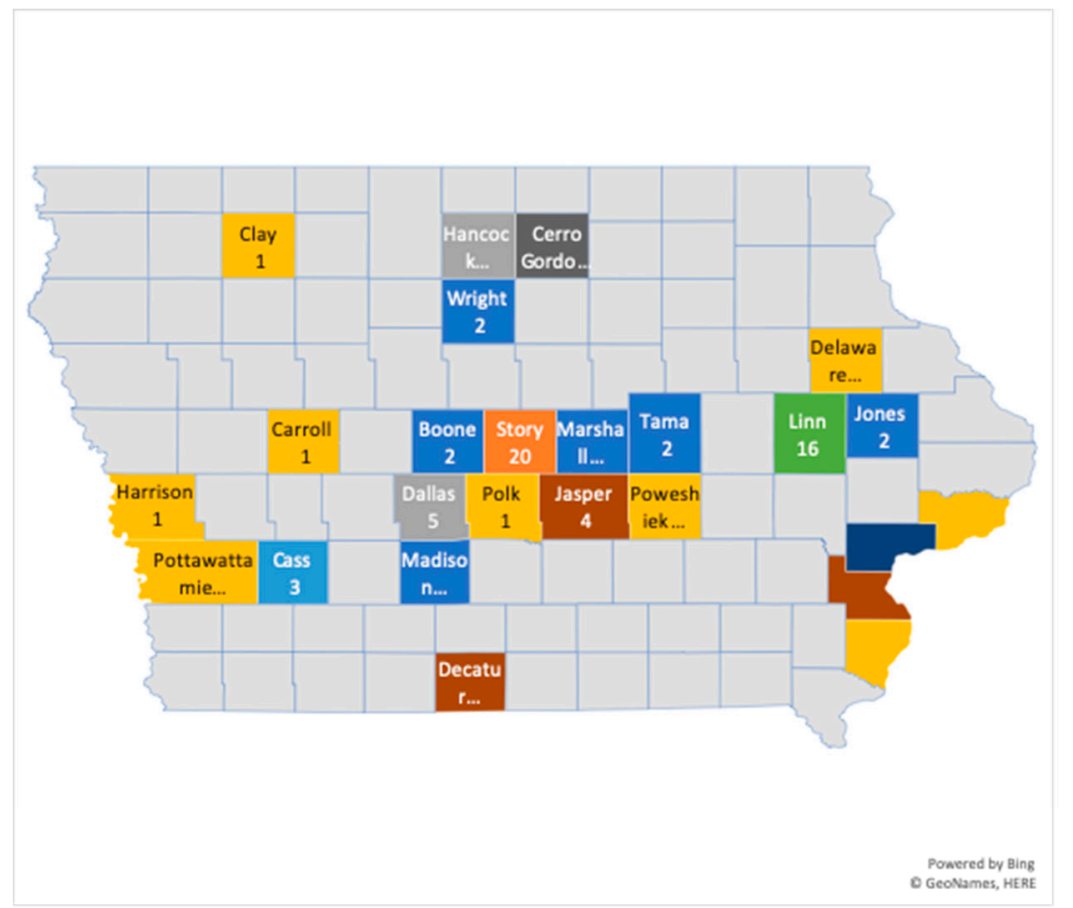

Figure 1. Iowa map illustrating number of water samples collected from counties in 2017-2018.

\section{Results and Discussion}

The quality of agricultural water used on produce farms is a critical factor in reducing food safety risks. There is limited information available for understanding the impact of different sources of irrigation water used by produce farms, each posing varying degrees of food safety risks [12]. In this study, the number of $E$. coli cell counts varied among water source samples. Among the 101 samples collected, 32 samples (31\%) contained E. coli colonies ranging from 1 to 68,000 cells per $100 \mathrm{~mL}$ water sample. According to the FSMA Produce Safety Rule, the E. coli population in agricultural water must not exceed a geometric mean of 126 cells $/ 100 \mathrm{~mL}$ and the standard threshold value of 410 cells $/ 100 \mathrm{~mL}$. Nine of these positive samples $(8.75 \%$, all surface waters) were contaminated beyond the FDA's maximum allowed limit [7]. Water sources contaminated above the FDA set standards to require corrective actions (such as employing bacterial die-off time, re-inspecting agricultural water system, water treatment) for direct use on covered produce [7]. The contamination in surface waters $(87.5 \%)$ was found to be highly prevalent, followed by well waters (5.8\%), as shown in Table 1 .

Table 1. Percentage of positive samples of generic Escherichia coli obtained from sixty Iowa fresh produce farm waters.

\begin{tabular}{cccc}
\hline Source & Number of Samples & Contaminated Samples & Percentage \\
\hline Surface Water & 32 & 28 & 87.5 \\
\hline Well Water & 69 & 4 & 5.8 \\
\hline
\end{tabular}

The results from this study agree with other studies that have shown that susceptibility of surface water (including ponds, lakes, and streams) to microbial contamination is much higher than groundwater (i.e., well water) sources [13]. Surface water has been shown through research to be more prone to contamination than any other water source because it is open to the environment, animals have easy access to it, rainfall events contribute to run off, and sewage and manure sludge could potentially be directly seeping into watersheds [3,14]. In a study by Crowe et al. [15], surface water has been reported to carry a high number of enteric pathogens. The literature also reported that a higher incidence of waterborne illnesses is associated with drinking water at times of intense 
rainfall $[16,17]$. However, no trends were observed in the data from this study regarding high contamination of surface waters $(88 \%)$ such as the same water source or the same region of the state. Contamination in groundwater is common in the United States. Between 1991 and 1992, most (76\%) of the 34 drinking water disease outbreaks have been traced back to contaminated wells $[5,18]$. Moreover, during 1981-1990, contaminated groundwater was responsible for $43 \%$ of reported outbreaks [19]. The surveillance data (2013-2014) on waterborne diseases and outbreaks reported a total of 42 drinking water-associated outbreaks that resulted in 1006 illnesses, 124 hospitalizations, and 13 deaths [20].

The E. coli analysis was conducted at two different time frames, $6 \mathrm{~h}$, and $24 \mathrm{~h}$. No statistical difference $(p>0.05)$ was observed between E. coli colony counts during these time intervals (Figure 2). While it is a small sample size, these results support the extension of the sample holding time to $24 \mathrm{~h}$ with samples stored at $<10^{\circ} \mathrm{C}$ for agricultural water samples from the surface, well, and municipal water sources. Our results differ from a study reported in 2003 that analyzed E. coli in water from 24 different sites across the USA and showed that the water analysis could be done beyond $8 \mathrm{~h}$ to detect E. coli if stored at $10^{\circ} \mathrm{C}$. However, another study reported water samples should be analyzed within $8 \mathrm{~h}$ to get accurate results [9]. The results from a study [10] conducted on stormwater and sewage show that water samples kept at $4{ }^{\circ} \mathrm{C}$ were not statistically different when analyzed for fecal coliforms at $7 \mathrm{~h}$ and greater than $24 \mathrm{~h}$ holding times. The study also supported the conclusion that sample storage could be extended to $24 \mathrm{~h}$ for analysis of microorganisms without altering the mean levels of E. coli, which is in accordance with the results of this paper. Another similar study [21] supported the results reported in this study, stating that extending sample holding time from 8 to $30 \mathrm{~h}$ does not affect the

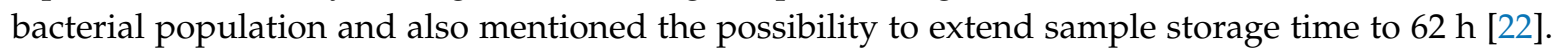
Extending sampling holding period promotes water testing by making it easier to access certified laboratories in the region through overnight shipment, coordination of delivery with other growers, or transporting by self. These standards will also assist with conformance with drinking water standards held throughout the world. For example, studies conducted in the European Union have reported use of ISO methods (commonly used ISO 7899-2 method) as per the requirements of European Drinking Water Directive 98/83/EG. These methods use 24-h sample holding time before the analysis of water samples, which is in agreement with the conclusion of this study [23,24]. Moreover, in Australia their drinking water standards are similar to the United States but hold stricter requirements for frequency and level of E. coli levels using AS/NZS 5667.5:1998 which requires samples held less than $24 \mathrm{~h}$ [25].

The average temperature of water samples collected at the source was $18.6^{\circ} \mathrm{C}$ with minimum and maximum readings of $9{ }^{\circ} \mathrm{C}$ and $30^{\circ} \mathrm{C}$. No significant correlation $(\mathrm{r}=0.20, p>0.05)$ was observed between water temperature and the E. coli cell count among different types of water sources. Study [26] described a significant correlation between E. coli and water temperature $(r=0.26, p<0.001)$ that sampled surface water from canal waters at multiple time points during a day. It can be hypothesized that this disparity between the studies is due to the sample size and regional differences between the southwest USA and Iowa, which might have helped reduce the microbial numbers. The southwest USA has increased exposure to the sun, warm air temperatures (monthly high of $21^{\circ} \mathrm{C}$ ), and low precipitation (monthly average of $0.97 \mathrm{~cm}$ ) [26].

Water plays a crucial food safety role in the production of fresh fruits and vegetables. Numerous direct points of contact between water and food from farm to fork make it a potential source of contamination and a food safety concern. The strict regulation of agriculture water quality for produce farms under the FSMA Produce Safety Rule means that all covered farms are required to have quantitative water tests using one of the nine certified methods, including EPA 1603. Considering the limitations of the 6-h sample holding time with all approved methods and few certified labs, many growers resist participating in water testing. Extending the holding time from $6 \mathrm{~h}$ to $24 \mathrm{~h}$ would help growers become compliant with the new regulation and would minimize food safety risks on their farm. This adjustment in the water testing method would also aid the FDA in its approach to preventing and reducing foodborne illnesses at the farm level, as defined in the FSMA Produce Safety Rule, and ultimately resulting in better protection of the US food system as a whole. 


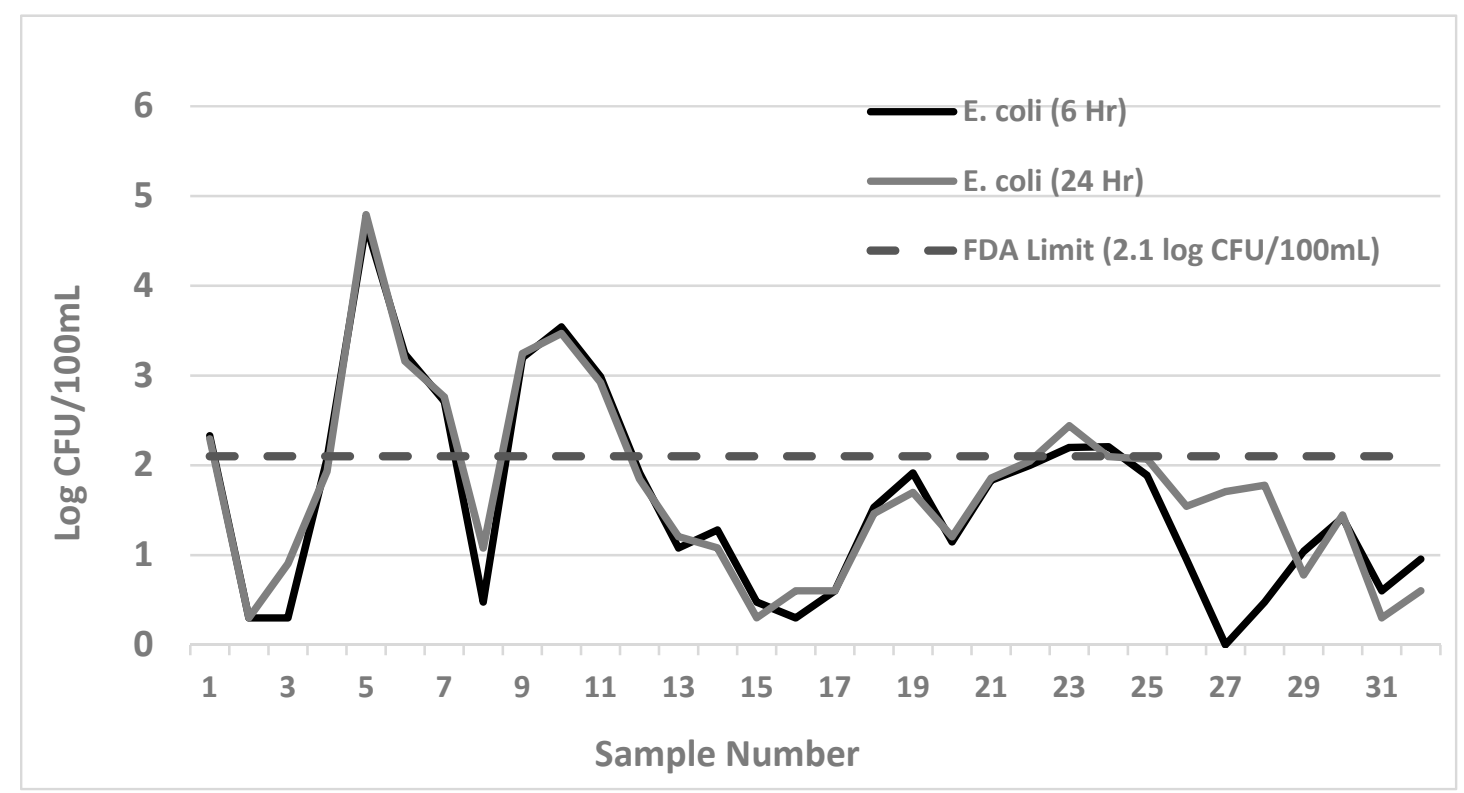

Figure 2. Generic Escherichia coli cell counts of 32 contaminated samples (69 samples tested at no detectable Escherichia coli) at $6 \mathrm{~h}$ and $24 \mathrm{~h}$ sample holding time obtained from sixty Iowa produce farms in 2017-2018.

Author Contributions: Conceptualization, A.S. and M.S.B.; Methodology, A.S., S.A., M.S.B.; Sample Collection, J.H. and M.S.B.; Sample Analysis, M.S.B.; Data Collection, M.S.B.; Writing- Original Draft Preparation, M.S.B.; reviewing and Editing, A.S., S.A.; Visualization, S.A., Manreet.

Funding: The project was funded by Iowa State University Department of Food Science and Human Nutrition.

Acknowledgments: The authors acknowledge all the growers from Iowa who participated in this study and assisted with sample collection. Also, the authors are grateful to the George Washington Carver Intern, Briana Young, who assisted with field visits and sample collection during her summer internship program in 2018.

Conflicts of Interest: The authors declare no conflict of interest.

\section{References}

1. Shanan, L. Irrigation development: Proactive planning and interactive management. In The Arid Frontier; Springer: Berlin, Germany, 1998; pp. 251-276.

2. Faour-Klingbeil, D.; Murtada, M.; Kuri, V.; Todd, E.C.D. Understanding the routes of contamination of ready-to-eat vegetables in the Middle East. Food Control 2016, 62, 125-133. [CrossRef]

3. Steele, M.; Odumeru, J. Irrigation water as source of foodborne pathogens on fruit and vegetables. J. Food Prot. 2004, 67, 2839-2849. [CrossRef] [PubMed]

4. Craun, M.F.; Craun, G.F.; Calderon, R.L.; Beach, M.J. Waterborne outbreaks reported in the United States. J. Water Health 2006, 4, 19-30. [CrossRef] [PubMed]

5. Reynolds, K.A.; Mena, K.D.; Gerba, C.P. Risk of waterborne illness via drinking water in the United States. In Reviews of Environmental Contamination and Toxicology; Springer: Berlin, Germany, 2008; pp. 117-158.

6. Centers for Disease Control and Prevention (CDC). Outbreak of E. coli Infections Linked to Romaine Lettuce November. 2018. Available online: Https:/Www.Cdc.Gov/Ecoli/2018/O157h7-11-18/Index.Html (accessed on 16 April 2019).

7. U.S. Food and Drug Administration. Standards for Growing, Harvesting, Packaging and Holding of Produce for Human Consumption CFR 112.44(b). Available online: https: //www.federalregister.gov/documents/2015/11/27/2015-28159/standards-for-the-growing-harvestingpacking-and-holding-of-produce-for-human-consumption (accessed on 15 April 2018).

8. U.S. Environmental Protection Agency. Method 1603: Escherichia coli (E. coli) in Water by Membrane Filtration Using Modified Membrane-thermotolerant Escherichia coli Agar (Modified MTEC); EPA 821-R-02-023; US Environmental Protection Agency: Washington, DC, USA, 2002. 
9. Pope, M.L.; Bussen, M.; Feige, M.A.; Shadix, L.; Gonder, S.; Rodgers, C.; Chambers, Y.; Pulz, J.; Miller, K.; Connell, K. Assessment of the effects of holding time and temperature on Escherichia coli densities in surface water samples. Appl. Environ. Microbiol. 2003, 69, 6201-6207. [CrossRef] [PubMed]

10. Selvakumar, A.; Borst, M.; Boner, M.; Mallon, P. Effects of sample holding time on concentrations of microorganisms in water samples. Water Env. Res 2004, 76, 67-72. [CrossRef] [PubMed]

11. McDaniels, A.E.; Bordner, R.H.; Gartside, P.S.; Haines, J.R.; Brenner, K.P.; Rankin, C.C. Holding effects on coliform enumeration in drinking water samples. Appl. Environ. Microbiol. 1985, 50, 755-762. [PubMed]

12. Decol, L.T.; Casarin, L.S.; Hessel, C.T.; Batista, A.C.F.; Allende, A.; Tondo, E.C. Microbial quality of irrigation water used in leafy green production in southern brazil and its relationship with produce safety. Food Microbiol. 2017, 65, 105-113. [CrossRef] [PubMed]

13. Uyttendaele, M.; Jaykus, L.A.; Amoah, P.; Chiodini, A.; Cunliffe, D.; Jacxsens, L.; Holvoet, K.; Korsten, L.; Lau, M.; McClure, P.; et al. Microbial hazards in irrigation water: standards, norms, and testing to manage use of water in fresh produce primary production. Compr. Rev. Food Sci. Food Saf. 2015, 14, 336-356. [CrossRef]

14. James, J. Overview of microbial hazards in fresh fruit and vegetables operations. Microb. Hazard Identif. Fresh Fruit Veg. 2006, 1-36.

15. Crowe, S.J.; Mahon, B.E.; Vieira, A.R.; Gould, L.H. Vital signs: Multistate foodborne outbreaks-United States, 2010-2014. MMWR Morb. Mortal. Wkly. Rep. 2015, 64, 1221-1225. [CrossRef] [PubMed]

16. Curriero, F.C.; Patz, J.A.; Rose, J.B.; Lele, S. The Association between extreme precipitation and waterborne disease outbreaks in the United States, 1948-1994. Am. J. Public Health 2001, 91, 1194-1199. [CrossRef] [PubMed]

17. Thomas, K.M.; Charron, D.F.; Waltner-Toews, D.; Schuster, C.; Maarouf, A.R.; Holt, J.D. A role of high impact weather events in waterborne disease outbreaks in Canada, 1975-2001. Int. J. Environ. Health Res. 2006, 16, 167-180. [CrossRef] [PubMed]

18. Moore, A.C.; Herwaldt, B.L.; Craun, G.F.; Calderon, R.L.; Highsmith, A.K.; Juranek, D.D. Surveillance for waterborne disease outbreaks-United States, 1991-1992. Morb. Mortal. Wkly. Rep. CDC Surveill. Summ. 1993, 1-22.

19. Craun, G.F. Waterborne disease outbreaks in the United States of America: Causes and prevention. World Health Stat. Q. 1992, 45, 192.

20. Benedict, K.M.; Reses, H.; Vigar, M.; Roth, D.M.; Roberts, V.A.; Mattioli, M.; Cooley, L.A.; Hilborn, E.D.; Wade, T.J.; Fullerton, K.E.; et al. Surveillance for waterborne disease outbreaks associated with drinking water-United States, 2013-2014. MMWR. Morb. Mortal. Wkly. Rep. 2017, 66, 1216-1221. [CrossRef] [PubMed]

21. Bushon, R.N.; Brady, A.M.G.; Lindsey, B.D. Holding-time and method comparisons for the analysis of fecal-indicator bacteria in groundwater. Environ. Monit. Assess. 2015, 187. [CrossRef] [PubMed]

22. Aulenbach, B.T. Bacteria holding times for fecal coliform by $\mathrm{mfc}$ agar method and total coliform and Escherichia coli by Colilert@-18 Quanti-Trayßmethod. Environ. Monit. Assess. 2010, 161, 147-159. [CrossRef] [PubMed]

23. Tanaro, J.D.; Piaggio, M.C.; Galli, L.; Gasparovic, A.M.C.; Procura, F.; Molina, D.A.; Vitón, M.; Zolezzi, G.; Rivas, M. Prevalence of Escherichia coli O157:H7 in surface water near cattle feedlots. Foodborne Pathog. Dis. 2014, 11, 960-965. [CrossRef] [PubMed]

24. Schets, F.M.; During, M.; Italiaander, R.; Heijnen, L.; Rutjes, S.A.; Van Der Zwaluw, W.K.; De Roda Husman, A.M. Escherichia coli O157:H7 in drinking water from private water supplies in The Netherlands. Water Res. 2005, 39, 4485-4493. [CrossRef] [PubMed]

25. Standards Australia/Standards New Zealand. Water Quality—Sampling. Part 5: Guidance on Sampling of Drinking Water and Water Used for Food and Beverage Processing; As/Nzs: Sydney, Australia, 1998.

26. Lothrop, N.; Bright, K.R.; Sexton, J.; Pearce-Walker, J.; Reynolds, K.A.; Verhougstraete, M.P. Optimal strategies for monitoring irrigation water quality. Agric. Water Manag. 2018, 199, 86-92. [CrossRef]

(C) 2019 by the authors. Licensee MDPI, Basel, Switzerland. This article is an open access article distributed under the terms and conditions of the Creative Commons Attribution (CC BY) license (http://creativecommons.org/licenses/by/4.0/). 